\title{
WS4
}

\section{Probabilistic Analysis of the New Plays in Petrel. Exploration Well Design Workshop}

\section{T.E. Topalova* (Schlumberger Information Solutions)}

\section{SUMMARY}

Systematic approach to new plays assessment, recently developed by Schlumberger, enables integrated evaluation of petroleum systems key elements, such as trap, reservoir, charge, seal, hydrocarbon migration and timing, is realized as Petroleum-Systems-Quick-Look module in Petrel 2012.

Play Chance Mapping module stores all inputs such as geological property maps, variables, transforms and subordinate chance maps, which go into creating the final play chance map. The process of COS map creation consist of several steps aimed on quantitative analysis of trap and reservoirs properties as well as estimation of seal quality and hydrocarbons charge volume.

The final step of this short exploration optimized planning workshop is selection of the most perspective new well location upon the results of integrated COS map. With renewed option well path design in Petrel 2012 explorers can create any type of vertical and directional wellbore they need for investigating most promising reservoirs at the selected prospect. Workshop is oriented on the specialists in exploration with the basic experience in Petrel software usage. 
Systematic approach to new plays assessment, recently developed by Schlumberger, enables integrated evaluation of petroleum systems key elements, such as trap, reservoir, charge, seal, hydrocarbon migration and timing, is realized as Petroleum-Systems-Quick-Look module in Petrel 2012.

Play Chance Mapping module stores all inputs such as geological property maps, variables, transforms and subordinate chance maps, which go into creating the final play chance map. The process of COS map creation consist of several steps aimed on quantitative analysis of trap and reservoirs properties as well as estimation of seal quality and hydrocarbons charge volume.

The final step of this short exploration optimized planning workshop is selection of the most perspective new well location upon the results of integrated COS map. With renewed option well path design in Petrel 2012 explorers can create any type of vertical and directional wellbore they need for investigating most promising reservoirs at the selected prospect. Workshop is oriented on the specialists in exploration with the basic experience in Petrel software usage.

\section{Вероятностная оценка поисковых объектов в Petrel. Планирование скважины. Практикум}

Системный подход Шлюмберже SIS к оценке новых территорий и изучению перспективных объектов геологоразведки (процесс оценки основных элементов нефтегазоносных систем) - с помощью специализированных модулей в Petrel 2012. Процесс построения карт геологических рисков включает в себя анализ геометрии ловушки, петрофизических свойств резервуара и покрышки, а также оценка вероятности наличия в системе углеводородного потенциала, достаточного для формирования залежи углеводородов. На основании построенной специалистами карты интегрального геологического риска производится выбор наиболее перспективного участка для заложения новой разведочной скважины и моделирования наиболее оптимальной траектории ствола. Слушатели данного практикума будут иметь возможность самостоятельно провести все необходимые процедуры для построения карты геологических рисков и выбора оптимального положения новой скважины в проекте Petrel 2012. Практикум рассчитан на специалистов с минимальным опытом работы в Petrel. 